\title{
Medicinal Plants of Arid and Semiarid Biomes of Russia
}

\author{
T. V. Dikareva ${ }^{a,}$ *, V. Yu. Rumyantsev ${ }^{a}$, M. S. Soldatov ${ }^{a}$, and S. M. Malkhazova ${ }^{a}$ \\ ${ }^{a}$ Moscow State University, Moscow, 119991 Russia \\ *e-mail: tanikdik@yandex.ru
}

Received August 13, 2020; revised August 19, 2020; accepted September 1, 2020

\begin{abstract}
The article analyzes a set of medicinal-plant species in arid and semiarid biomes of Russia. The species diversity of medicinal plants in general, as well as those used to treat diseases of various classes, is determined. A statistical analysis of the relationships between the number of species of medicinal plants in regional biomes and climatic indices is carried out; the corresponding thematic schematic maps are constructed and analyzed. It is shown that the number of medicinal-plant species is related to the total biome species number. This, in turn, is determined by the geographic location, which determines the average annual temperature and precipitation in the regions. The closest established relationship was between the number of medicinal-plant species and the average annual air temperatures. A relatively high relationship was found between the species number and the average annual precipitation. In the analysis of the relationship between the number of medicinal-plant species used to treat certain classes of diseases and the climatic factors, the picture turned out to be similar.
\end{abstract}

Keywords: medicinal plants, arid and semiarid biomes, climatic indices, correlation analysis

DOI: $10.1134 / \mathrm{S} 2079096121010054$

\section{INTRODUCTION}

The health of the population in the 21st century is becoming a high priority value for every state and the entire global community. As the experience of combating the coronavirus pandemic has shown, the protection of public health is a complex problem that depends on numerous natural and social factors. The plant biodiversity of a particular region plays a significant role in shaping the health of its population. Health conditions can be affected not only by plants used in agriculture but also by allergenic, poisonous, and medicinal plants. This is why the floral composition in inhabited places and recreation areas is very important for the characterization of the living conditions of the population.

Medicinal are those that, acting upon the body of a sick person or animal, block the development of the disease, contribute to the elimination of the causes of its occurrence, and normalize the impaired functional activity of individual organs, systems, or the body as a whole (Atlas arealov..., 1983). This positive effect is due to the content of various biologically active substances in them. These substances are found in plants in very small quantities. They have very strong specific properties. Therefore, their healing effect is observed only at strictly defined, usually very small, doses, above which the drug becomes a poison that causes severe poisoning. Medicinal plants are used in folk and traditional medicine for prophylactic and therapeutic purposes. To date, there are more than 350000 plant species that are recognized as medicinal (Medical and geographical..., 2019).

This paper analyzes the set of medicinal-plant species in the zonal arid and semiarid (subarid) biomes of Russia. We have taken these biomes as the initial region for analysis, since, according to the data of some studies (Nikolaevsky et al., 1987), an increased diversity of this group of species is observed in them.

The goal of the work is to identify the regularities in the distribution of species diversity of medicinal plants in arid and semiarid biomes. The tasks included the identification of the species diversity of medicinal plants in general and for various classes of diseases, a statistical analysis of correlations between the number of medicinal-plant species in regional biomes and climatic indices, and the construction of appropriate thematic schematic maps and analyzing them.

\section{MATERIALS AND METHODS}

The used methodological techniques were tested by the authors in their analysis of the distribution of allergenic people in Russia (Dikareva and Rumyantsev, 2015a, 2015b) and poisonous (Dikareva et al., 2017, 2018) plants.

The study was carried out based on the map Biomes of Russia (Ogureeva, 2016; Ogureeva et al., 2018). The regional biomes shown on this map are the constituent parts of biomes of the planetary level, which reflect the zonal-regional features of the vegetation cover of Rus- 


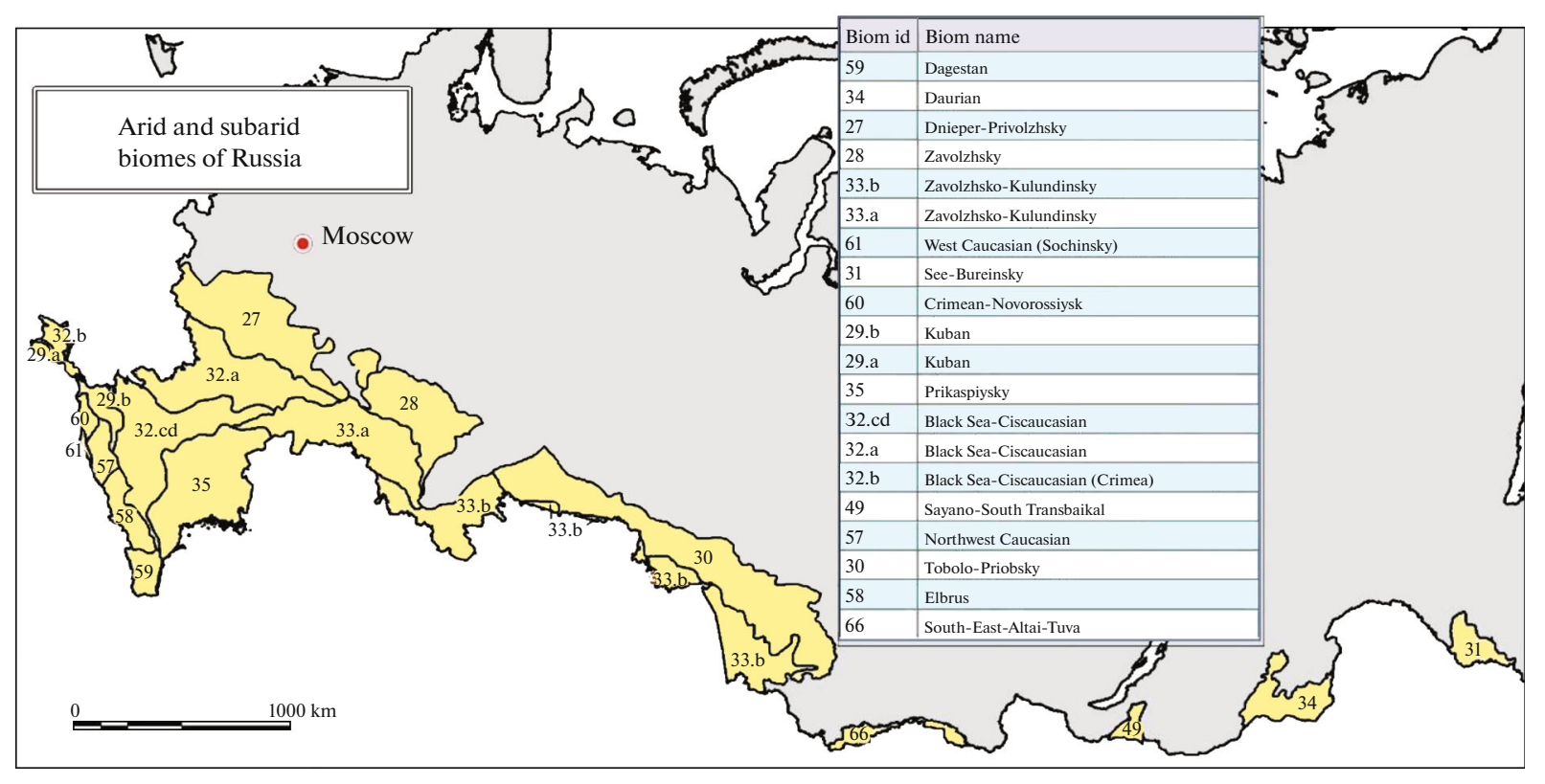

Fig. 1. Regional biomes included in the analysis.

sia (Kotova and Ogureeva, 2007; Ogureeva, 2012, 2016).

The analysis included 20 regional biomes (Fig. 1; Ogureeva et al., 2018). Initially, these were only plain zonal semiarid (subarid) and arid biomes (forest-steppe, steppe, and desert). Only the forest-steppe strip, which was separated on the map by the deciduous-forests border, was taken from biome 27 (Dneprovsko-Volga) (Ogureeva et al., 2018). Only the plain forest-steppe part was taken from biome 49 (Sayano-South Zabaikalsky) in accordance with the map Zones and Types of Zonality of Vegetation of Russia and Adjacent Countries (Zony $i$ tipy..., 1999).

After preliminary consideration and discussion, the analysis also included the mountain biomes of the Caucasus and Crimea, which are traditionally not considered arid. The main reason for this was the calculation of the De Martonne aridity index (De Martonne, 1925; Handbook on drought indicators..., 2016). The arid index (AI) (Fig. 2) is the quotient the average annual precipitation $(R)$ divided by the sum of the average annual air temperature $(T)$ increased by 10 , i.e., $\mathrm{AI}=R /(T+10)$. The lowest index values correspond to the highest aridity. This index is widely used both abroad and in Russia (Kazeev et al., 2015; Baltas, 2007). The data on air temperature and precipitation for the calculation of the aridity index were taken directly from the map Biomes of Russia (Ogureeva et al., 2018), where they are given in the form of climadiagrams for each biome. If there was more than one climatogram for a biome, the values of the indices were averaged.

Analysis of the AI values for the mountain biomes of the Caucasus and Crimea showed that they are quite comparable with those for zonal subarid biomes, often demonstrating an even more significant degree of aridity (Fig. 2). However, some comments are needed.

The vegetation of the mountain biomes of the Caucasus and Crimea is characterized by altitudinal zonation; the climatic conditions change with altitude, which determines the appearance of the vegetation. All of these biomes, according to the classification (Ogureeva et al., 2018), belong to the group of nemoral coniferous-deciduous and deciduous forests. However, xerophytic forest-steppe vegetation is widespread in the lower belts of the northern Caucasian mountains (500 m a.s.1. Baltic system (BS) and above). Due to the anthropogenic influence (grazing, hay-mowing), it sometimes rises up to the belt of subalpine meadows (Zony i tipy..., 1999).

The eastern part of the northern slopes of the Caucasus is characterized by foothill deserts that turn into a belt of wormwood-cereal dry steppes and xerophytic light forests with shiblyak and fragments of hornbeam-oak forests (300-500 m asl BS). This is a belt of a type of xerophytic, mountain forest-steppe with arid woodlands. Above this, there is a belt of oak, hornbeam, and beech forests $(500-1800 \mathrm{~m})$, which are not preserved everywhere and are often combined with areas of secondary steppes. A similar pattern of vegetation distribution with height is characteristic of the Crimea-Novorossiisk biome, where xerophytic light forests are widespread in combination with dry-steppe vegetation.

Thus, the vegetation of the lower mountain belts of most biomes of the Caucasus is sufficiently consistent with the concepts of "subarid and arid ecosystems." 


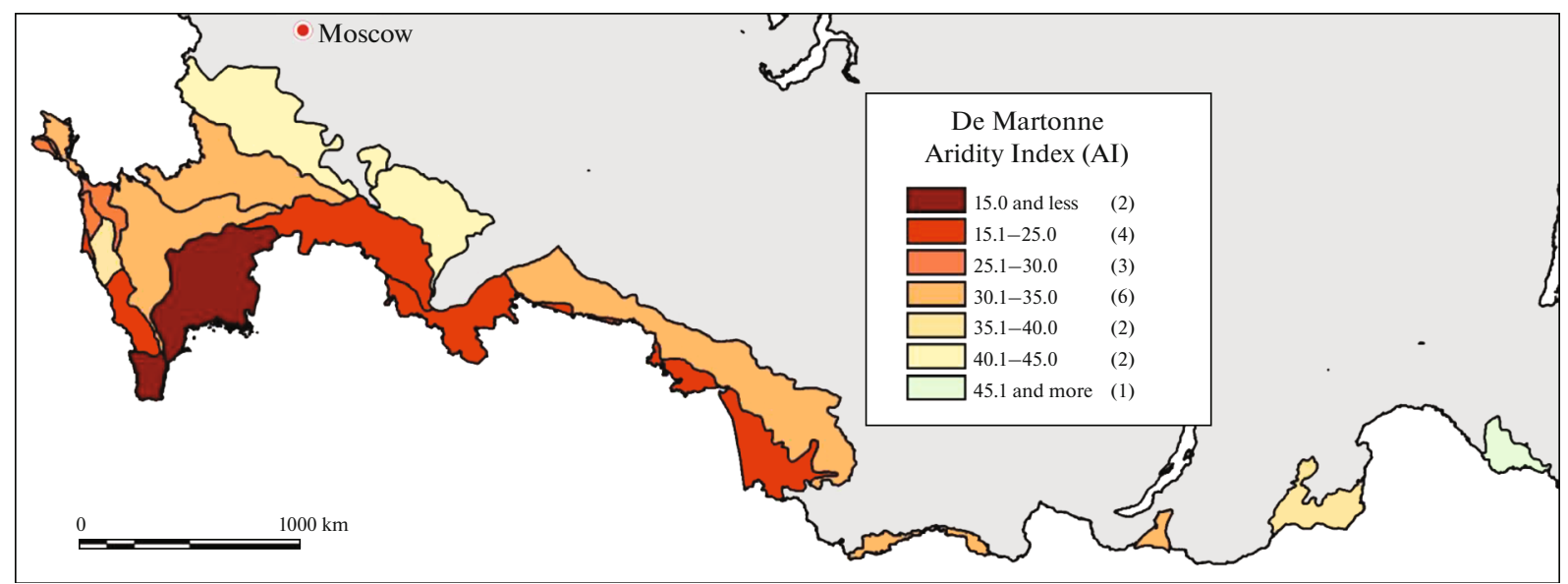

Fig. 2. De Martonne aridity index (here and in Figs. 3-8, brackets indicate the number of biomes in the gradation).

The subtropical Sochi biome stands somewhat apart, but the lower mountain belt here, due to anthropogenic impact, is very diverse and includes shrub forbcereal wastelands, fields, xerophytic forests, and the surrounding settlements. The relatively similar bioclimatic conditions and geographic proximity allow many medicinal plants characteristic of other regions of the Caucasus to live here. Analysis of the similarity of the flora of medicinal plants in the biomes of the Caucasus and Crimea (Table 1) showed a high degree of their commonality.

The analysis included 214 species of medicinal plants according to the database Medicinal Plants of Russia (Lekarstvennye..., 2019). These include only wild plants of arid and semiarid regions; the species can also be found in agriculture, but it must also live in the wild. A separate analysis was carried out for medicinal plants used to treat three disease classes according to the WHO IC-10 classification (International statistical classification..., 2019): respiratory diseases (grade 10), 60 types; diseases of the circulatory system (grade 9), 70 types; diseases of the digestive system (grade 11), 100 types.

Data on the ranges of the considered species were obtained from the keys to higher vascular plants (Grossheim, 1949; Rubtsov, 1972; Gubanov et al., 1995; Sosudistye rasteniya..., 1995), as well as from some atlases (Atlas arealov..., 1983; Agroekologicheskii atlas..., 2015; Mediko-geograficheskii atlas..., 2019). The presence of a specific plant species in the biome was defined by the presence of at least an insignificant part of its range within the boundaries of a given section (regional biome).

The total number of medicinal-plant species and the number of medicinal-plant species used to treat the above classes of diseases were determined for each of the 20 analyzed biomes. The materials were organized with Visual FoxPro 9.0 DBMS in a computer database linked to a digital base map in the MapInfo
15.0 Professional GIS environment. A series of schematic maps of the distribution of medicinal plants in the regional biomes of Russia was compiled on this basis. The Pearson's pair correlation coefficients were calculated in the STATISTIKA 6.0 program. They characterize the relationship between the number of species of medicinal plants in the above categories with the indices designated below as factors that may affect the distribution of these species.

\section{RESULTS AND DISCUSSION}

Several working hypotheses were considered: (1) the number of medicinal-plant species depends on the total number of vascular plant species in a particular biome and the position of the latter in the system of natural zoning of the territory, which, in turn, is determined by the most important climatic factors, such as the average annual air temperature and average annual precipitation; (2) the number of medicinal-plant species is directly related to climatic factors and, to a lesser extent, depends on the total biome species number; (3) the maximum number of taxa of medicinal plants is characteristic of the most arid territories.

Two groups are accepted as factors that are likely to influence the number of medicinal-plant species in biomes.

Table 1. Similarity of the floristic composition of medicinal plants in subarid biomes of the Crimea and the Caucasus according to the Jaccard coefficient

\begin{tabular}{c|c|c|c|c|c}
\hline No. & 57 & 58 & 59 & 60 & 61 \\
\hline 57 & 1.00 & 0.87 & 0.61 & 0.73 & 0.83 \\
58 & & 1.00 & 0.80 & 0.69 & 0.75 \\
59 & & & 1.00 & 0.70 & 0.73 \\
60 & & & & 1.00 & 0.83 \\
61 & & & & & 1.00 \\
\hline
\end{tabular}

ARID ECOSYSTEMS Vol. $11 \quad$ No. 12021 


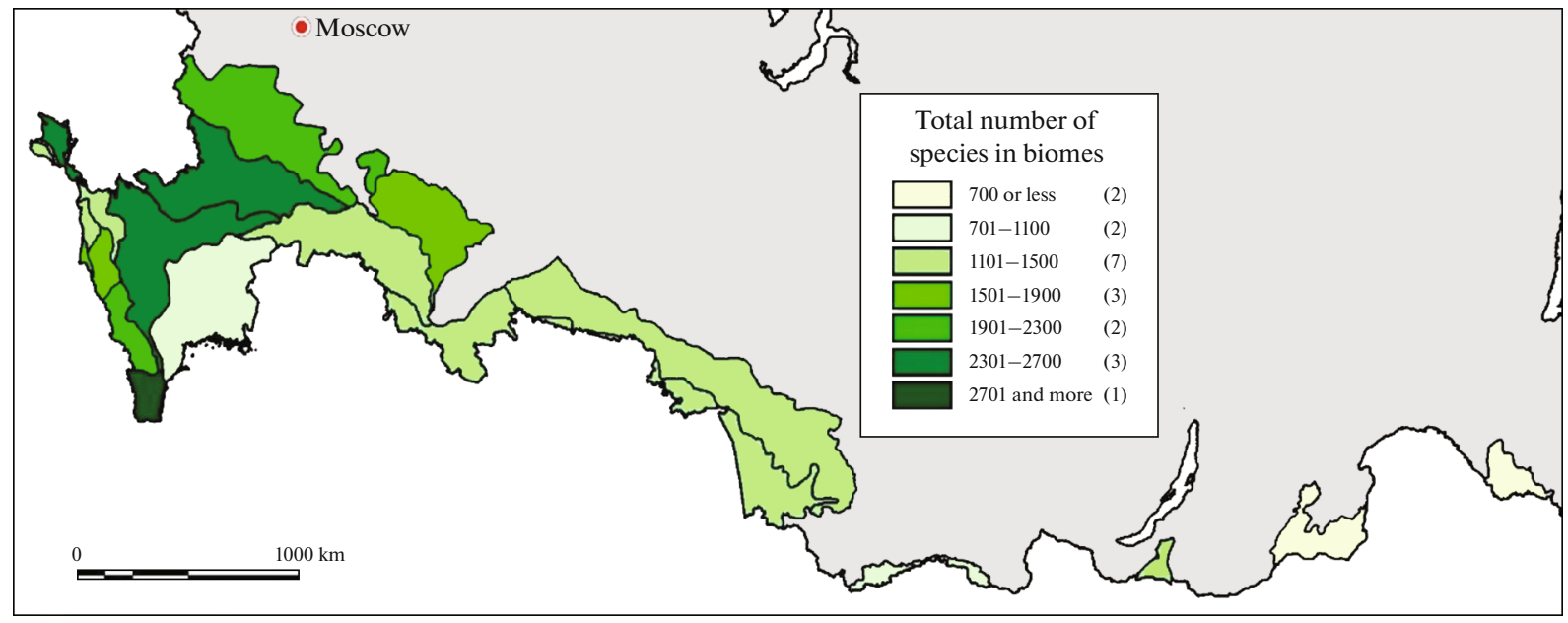

Fig. 3. Total number of vascular plant species in biomes.

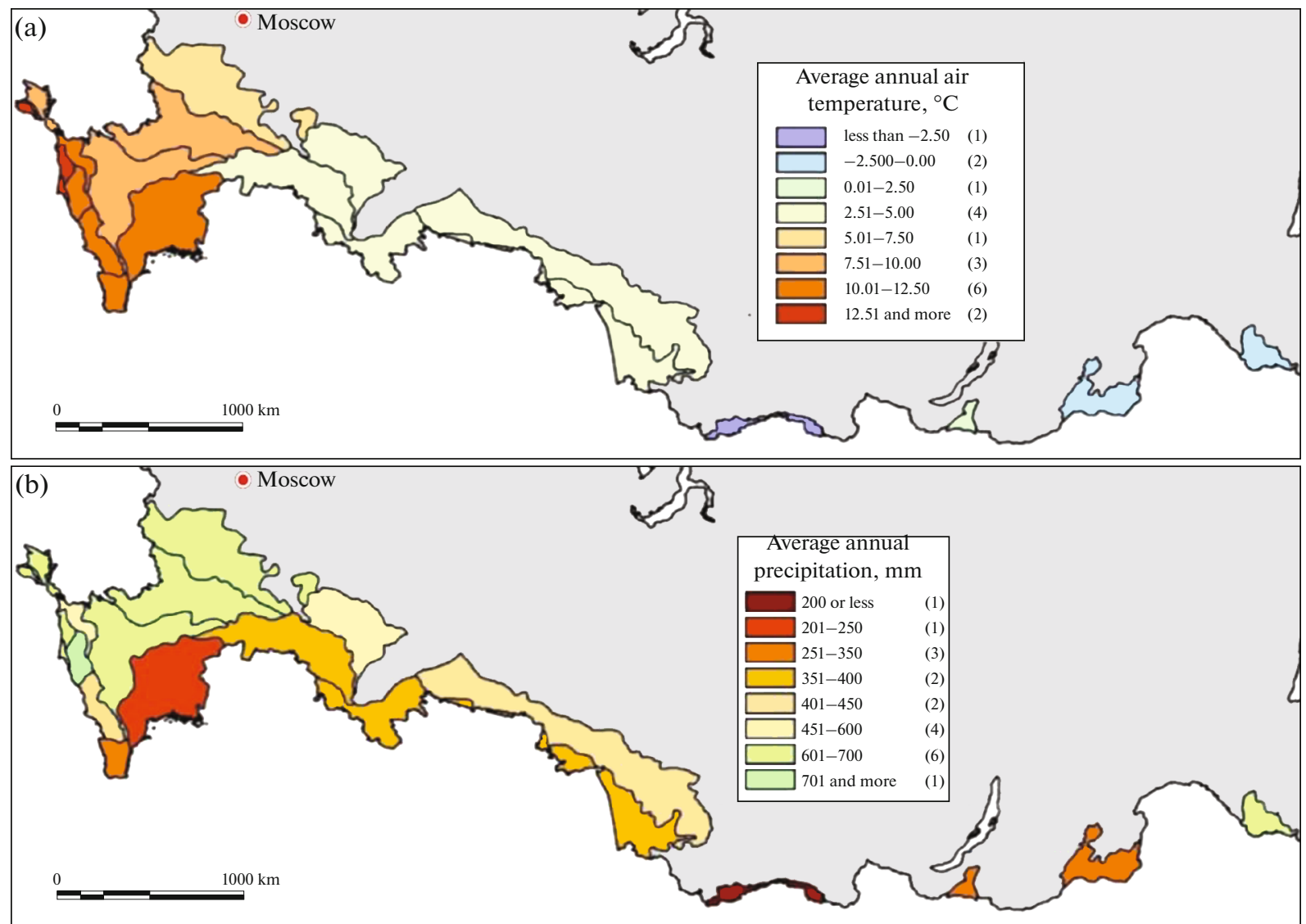

Fig. 4. Climatic factors: (a) average annual air temperature in ${ }^{\circ} \mathrm{C}$; (b) average annual precipitation in $\mathrm{mm}$.

1. The total number of vascular plant species in the biome (taken directly from the map Biomes of Russia; Ogureeva et al., 2018; Fig. 3).

2. Climatic factors (Fig. 4), as well as the AI as discussed above (Fig. 2).

In total, 214 species of medicinal plants belonging to 70 families were identified in the arid and semiarid biomes of Russia, as indicated above. The largest number of species include the families Compositae (24 species), Rosaceae (19), legumes (13), and Umbelliferous (12), which is generally typical of cenoses of arid spaces (meadow steppes, steppes, and desert steppes) (Tables 2, 3). The relatively high proportion of orchids (16 species) is mainly due to their 
Table 2. Families with the largest number of medicinalplant species

\begin{tabular}{l|c}
\hline \multicolumn{1}{c|}{ Family } & $\begin{array}{c}\text { Number } \\
\text { of species }\end{array}$ \\
\hline Apiaceae (Umbelliferae)-Umbelliferae & 12 \\
Asteraceae (Compositae)-Asteraceae & 24 \\
Fabaceae (Leguminosae)-Legumes & 13 \\
Orchidaceae-Orchidaceae & 16 \\
Ranunculaceae-Buttercup & 9 \\
Rosaceae-Rosaceae & 19 \\
Solanaceae-Solanaceae & 8 \\
\hline
\end{tabular}

confinement to the communities of the mountainous territories of the Crimea and the Caucasus, as well as to the forest communities of the forest-steppe zone. Relatively few, less than ten species, include the families of labiate (nine species), buttercup (nine species), and nightshade (eight species). Some families include three to four species, e.g., lamb, sumac, birch, heather, etc. The largest number of families (54) includes no more than one to two medicinal species.

The number of species reflected on the map of biomes of Russia was taken as the total biome species number (Table 3) (Fig. 3; Ogureeva et al., 2018). The largest species number was noted for the small Dagestan biome (2800 species). The number was somewhat lower for the Black Sea-Ciscaucasia and DnieperVolga biomes. The smallest number of plant species is in the eastern biomes, Daursky and Ze-Buriinsky.

The total number of medicinal-plant species in biomes is distributed somewhat differently. Most of them were recorded in the large northern DnieperVolga biome (129). There are somewhat fewer medicinal plants than in the indicated biome in small southern biomes, Crimea-Novorossiisk (127) and western Caucasia (Sochi; 122). An even smaller number of species were recorded for the Dagestan biome: 111 of 214 species of medicinal plants. The smallest number of species is found in the Zeya-Buriinsky (58) and Daursky (59) biomes. Relatively few medicinal plants were recorded in the desertified Caspian biome (69; Fig. 5).

It can be assumed that the number of medicinalplant species is related both to the total biome species number, which, in turn, is determined by the geographic location that determines the climatic indices in regional biomes and to these indices themselves (Table 4).

The Pearson pairwise coefficients were calculated for the following pairs:

Table 3. Number of medicinal-plant species and all vascular plants in the biomes

\begin{tabular}{|c|c|c|c|}
\hline Biome no. & Biome name & $\begin{array}{l}\text { Number of medicinal-plant } \\
\text { species in the biome }\end{array}$ & $\begin{array}{l}\text { Total number of vascular plant } \\
\text { species in the biome }\end{array}$ \\
\hline 27 & Dnieper-Volga & 129 & 2300 \\
\hline 28 & Zavolzhsky & 120 & 1880 \\
\hline 29.a & Kuban & 107 & 1150 \\
\hline 29.b & Kuban & 106 & 1150 \\
\hline 30 & Tobolo-Priobsky & 101 & 1450 \\
\hline 31 & Zee-Bureinsky & 58 & 480 \\
\hline 32.a & Black Sea-Ciscaucasia & 116 & 2350 \\
\hline 32.b & Black Sea-Ciscaucasia (Crimea) & 83 & 2350 \\
\hline 32.cd & Black Sea-Ciscaucasia & 98 & 2350 \\
\hline 33.a & Zavolzhsko-Kulundinsky & 78 & 1350 \\
\hline 33.b & Zavolzhsko-Kulundinsky & 89 & 1350 \\
\hline 34 & Daursky & 58 & 655 \\
\hline 35 & Caspian & 69 & 1050 \\
\hline 49 & Sayano-Southern Transbaikal & 64 & 1500 \\
\hline 57 & Northwestern Caucasia & 114 & 1900 \\
\hline 58 & Elbrus & 109 & 2300 \\
\hline 59 & Dagestan & 111 & 2800 \\
\hline 60 & Crimea-Novorossiysk & 127 & 1415 \\
\hline 61 & Western Caucasia (Sochi) & 122 & 1850 \\
\hline 66 & Southeastern Altai-Tuva & 66 & 1075 \\
\hline
\end{tabular}




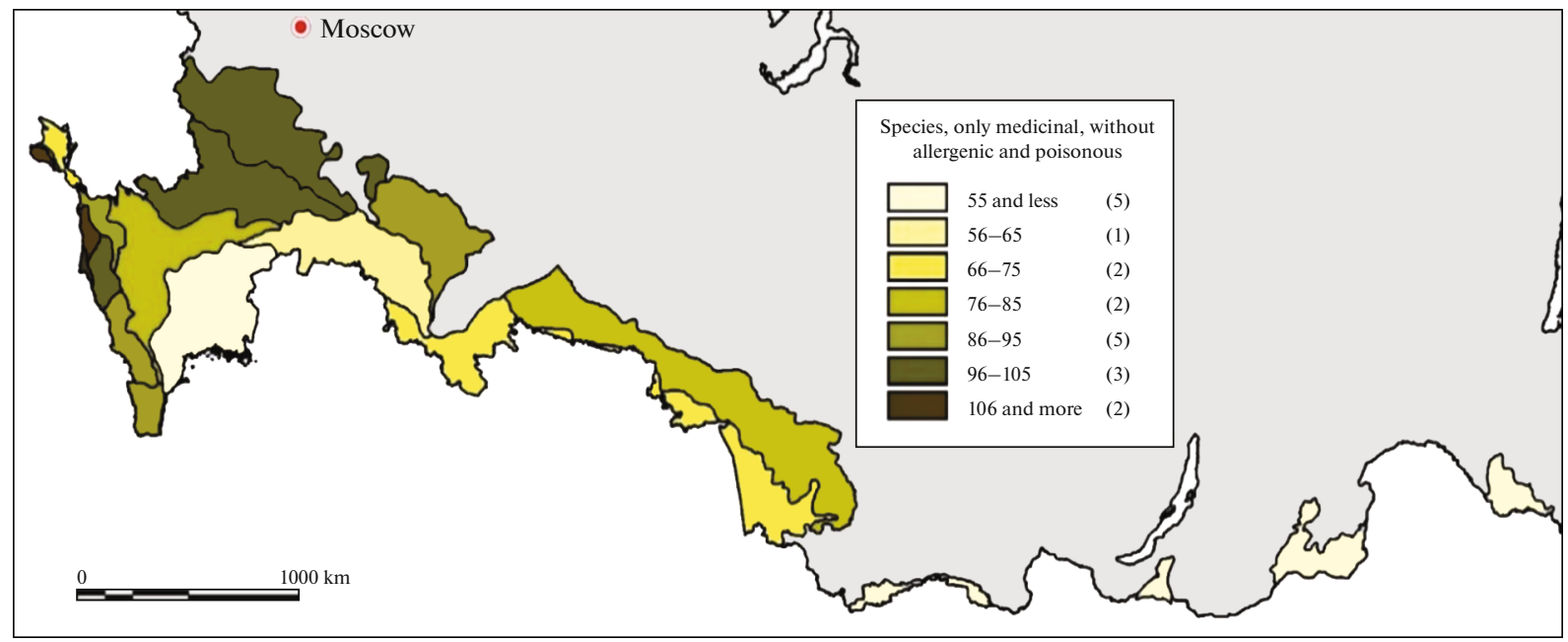

Fig. 5. Number of medicinal-plant species in biomes.

-Total number of vascular plant species in biomes $\leftrightarrow$ AI.

-Total number of vascular plant species in biomes $\leftrightarrow$ Average annual air temperature $\left({ }^{\circ} \mathrm{C}\right)$.

-Total number of vascular plant species in biomes $\leftrightarrow$ Average annual precipitation ( $\mathrm{mm}$ ).

-Number of medicinal-plant species $\leftrightarrow$ AI.
-Number of medicinal-plant species $\leftrightarrow$ Average annual air temperature $\left({ }^{\circ} \mathrm{C}\right)$.

-Number of medicinal-plant species $\leftrightarrow$ Average annual precipitation $(\mathrm{mm})$.

Table 5 shows the results of the analysis performed.

The number of medicinal-plant species has a rather high positive relationship with the total biome species number $(0.63)$. Thus, the total species number, to

Table 4. Climatic indices in biomes

\begin{tabular}{l|l|c|c|c}
\hline Biome no. & \multicolumn{1}{|c|}{ Biome name } & Average annual temperature, ${ }^{\circ} \mathrm{C}$ & Amount of precipitation, $\mathrm{mm}$ & AI \\
\hline 27 & Dnieper-Volga & 5.6 & 642 & 41.15 \\
28 & Zavolzhsky & 3.8 & 589 & 42.68 \\
$29 . \mathrm{a}$ & Kuban & 12.4 & 560 & 25 \\
$29 . \mathrm{b}$ & Kuban & 12.4 & 560 & 25 \\
30 & Tobolo-Priobsky & 3.2 & 433 & 32.8 \\
31 & See-Bureinsky & -0.6 & 641 & 68.19 \\
$32 . \mathrm{a}$ & Black Sea-Ciscaucasia & 9.6 & 603 & 30.77 \\
$32 . \mathrm{b}$ & Black Sea-Ciscaucasia (Crimea) & 9.6 & 603 & 30.77 \\
$32 . \mathrm{cd}$ & Black Sea-Ciscaucasia & 9.6 & 603 & 30.77 \\
$33 . \mathrm{a}$ & Zavolzhsko-Kulundinsky & 4.7 & 367 & 24.97 \\
$33 . \mathrm{b}$ & Zavolzhsko-Kulundinsky & 4.7 & 367 & 24.97 \\
34 & Daursky & -2.3 & 300 & 38.96 \\
35 & Caspian & 10 & 202 & 10.1 \\
49 & Sayano-Southern Transbaikal & 0 & 342 & 34.2 \\
57 & Northwestern Caucasia & 11.8 & 772 & 35.41 \\
58 & Elbrus & 10.5 & 439 & 21.41 \\
59 & Dagestan & 12 & 300 & 13.64 \\
60 & Crimea-Novorossiysk & 13.1 & 618 & 26.75 \\
61 & Western Caucasia (Sochi) & 14 & 574 & 23.92 \\
66 & Southeastern Altai-Tuva & -4.5 & 165 & 30 \\
\hline
\end{tabular}


Table 5. Relationship between the number of plant species and determinants by the Pearson correlation coefficients

\begin{tabular}{l|c|c|c|c}
\hline \multirow{2}{*}{\multicolumn{2}{c}{ Indices }} & \multicolumn{4}{|c}{ Factors } \\
\cline { 2 - 5 } & AI & average temperature, ${ }^{\circ} \mathrm{C}$ & amount of precipitation, mm & all types in biomes \\
\hline All species in the biomes & -0.32 & 0.50 & 0.29 & 1.00 \\
Medicinal-plant species in biomes & -0.22 & 0.72 & 0.60 & 0.63 \\
\hline
\end{tabular}

All correlations are significant at $p<0.05$.

Table 6. Distribution of the number of medicinal-plant species by disease class according to the WHO classification (one species can be in several classes)

\begin{tabular}{c|l|c}
\hline Disease class no. & & \multicolumn{1}{|c}{ Disease class } \\
\hline 1 & Some infectious and parasitic diseases & 14 \\
2 & Neoplasms & 9 \\
3 & Diseases of the blood and blood-forming organs & 0 \\
4 & and certain disorders involving the immune mechanism & 7 \\
5 & Endocrine system diseases, eating disorders, and metabolic disorders & 11 \\
6 & Mental and behavioral disorders & 35 \\
7 & Diseases of the nervous system & 13 \\
8 & Diseases of the eye and its adnexa & 0 \\
9 & Diseases of the ear and mastoid & 77 \\
10 & Diseases of the circulatory system & 60 \\
11 & Respiratory diseases & 100 \\
12 & Diseases of the digestive system & 33 \\
13 & Diseases of the skin and subcutaneous tissue & 21 \\
14 & Diseases of the musculoskeletal system and connective tissue & 35 \\
15 & Diseases of the genitourinary system & 13 \\
16 & Pregnancy, childbirth, and the puerperium & 0 \\
17 & Certain conditions arising in the perinatal period & 0 \\
18 & Congenital anomalies (malformations), deformities and chromosomal abnormalities & 0 \\
19 & Symptoms, signs, and abnormalities detected in clinical & 32 \\
\hline
\end{tabular}

some extent, determines the number of medicinal plants.

The closest positive relationship was established between the number of medicinal-plant species and average annual air temperatures (0.72). A relatively high relationship (0.60) was established between the species number and the average annual precipitation.

However, it is very important that the relationship between the number of medicinal-plant species and the AI, which is determined by the ratio of the mean annual air temperature and the amount of precipitation, an integral indicator of the aridity of the territory, turned out to be low and negative. The negativity of the relationship is understandable, since the higher the degree of aridity of the territory is, the lower is the value of the index. The bottom line is that there are positive relationships between the species number and the average annual temperature and the amount of precipitation, which are "antagonists" within the AI, i.e., the number of medicinal-plant species in biomes is hardly related to the aridity of the latter, which to some extent contradicts the results of earlier studies (Nikolaevsky et al., 1987).

Further, the distribution of the number of medicinal plants used to treat various classes of diseases according to the WHO classification was considered (Table 6), according to the database Medicinal Plants of Russia (Lekarstvennye..., 2019).

Table 6 shows that the largest number of medicinal-plant species in arid and semiarid biomes is used to treat diseases of the digestive system, circulatory system, and respiratory system. There are absolutely no plant species used to treat diseases classes such as those of the blood and blood-forming organs and cer- 


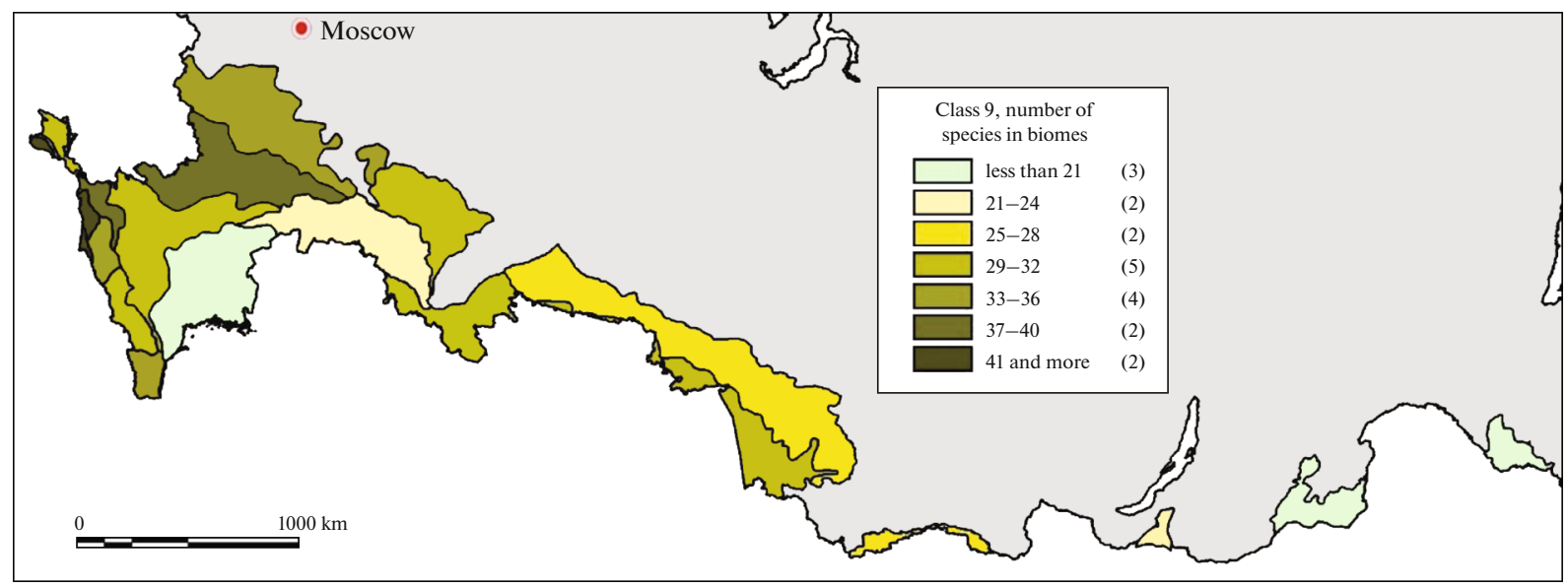

Fig. 6. Number of medicinal-plant species used to treat diseases of the circulatory system (class 9) in biomes.

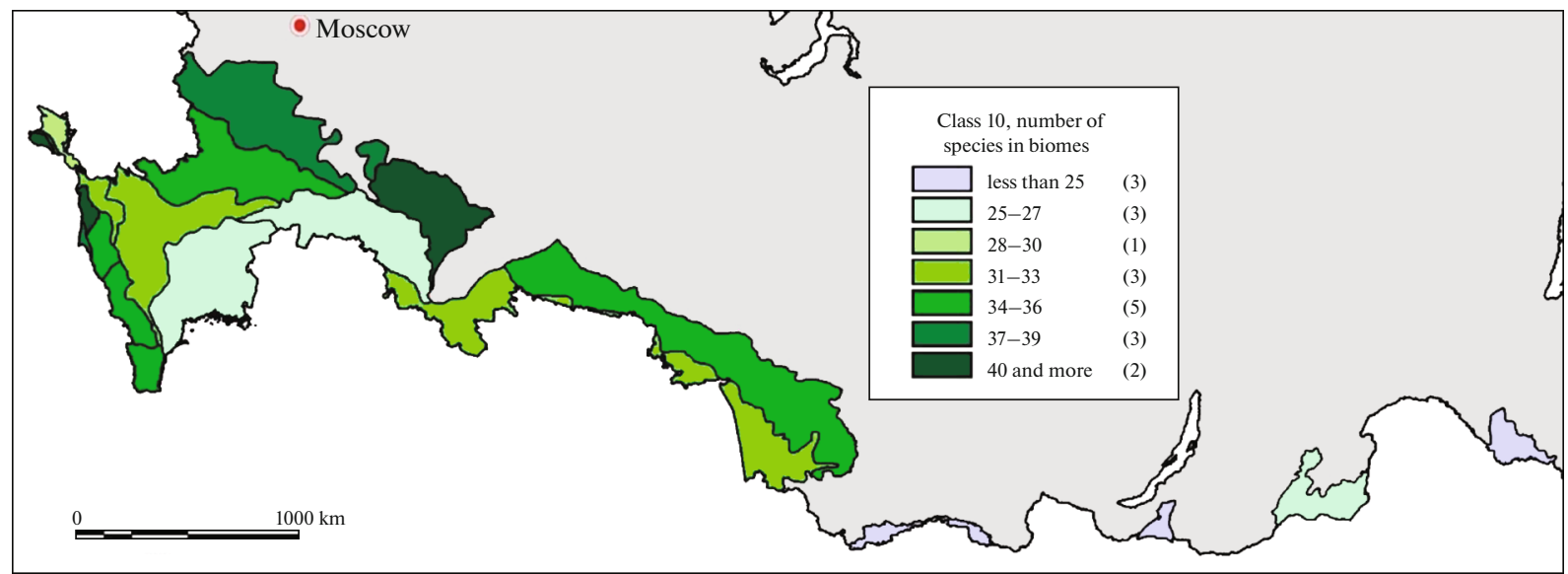

Fig. 7. Number of medicinal-plant species used to treat respiratory diseases (class 10) in biomes.

tain disorders involving the immune mechanism; diseases of the ear and mastoid; individual conditions arising in the perinatal period; congenital anomalies (malformations), deformities, and chromosomal abnormalities; and symptoms, signs, and abnormalities identified in clinical and laboratory studies that are not classified elsewhere.

Schematic maps were compiled by biome for the number of medicinal-plant species used in the treatment of the analyzed classes of diseases: class 9 (diseases of the circulatory system); class 10 (diseases of the respiratory system), and class 11 (diseases of the digestive system; Figs. 6-8).

The schematic map of the distribution of medicinal-plant species used to treat diseases of the circulatory system in the considered biomes (Fig. 6) shows that their greatest diversity is observed in the Black Sea-Ciscaucasia, Crimea-Novorossiisk, and the Kuban biomes.

The greatest variety of medicinal-plant species used to treat respiratory diseases and diseases of the digestive system in the considered biomes (Figs. 7, 8) is observed in the Dnieper-Volga, Black Sea-Ciscaucasia, Zavolzhsky, Dagestan, northwestern Caucasia, Crimea-Novorossiysk, western Caucasia (Sochi), and Kuban biomes.

The Pearson correlation coefficients were calculated for the above classes of diseases (Table 7):

-Number of medicinal-plant species $\leftrightarrow$ AI;

-Number of medicinal-plant species $\leftrightarrow$ Average annual air temperature $\left({ }^{\circ} \mathrm{C}\right)$;

-Number of medicinal-plant species $\leftrightarrow$ Average annual precipitation $(\mathrm{mm})$.

The medicinal species of all three considered classes have a generally very high correlation with the total number of medicinal species in biomes (0.89-0.99).

The closest relationship was established between the number of plant species used to treat class-9 diseases (diseases of the circulatory system) and the average temperature (0.96); there was a relatively high relationship with the total biome species number (0.58) 


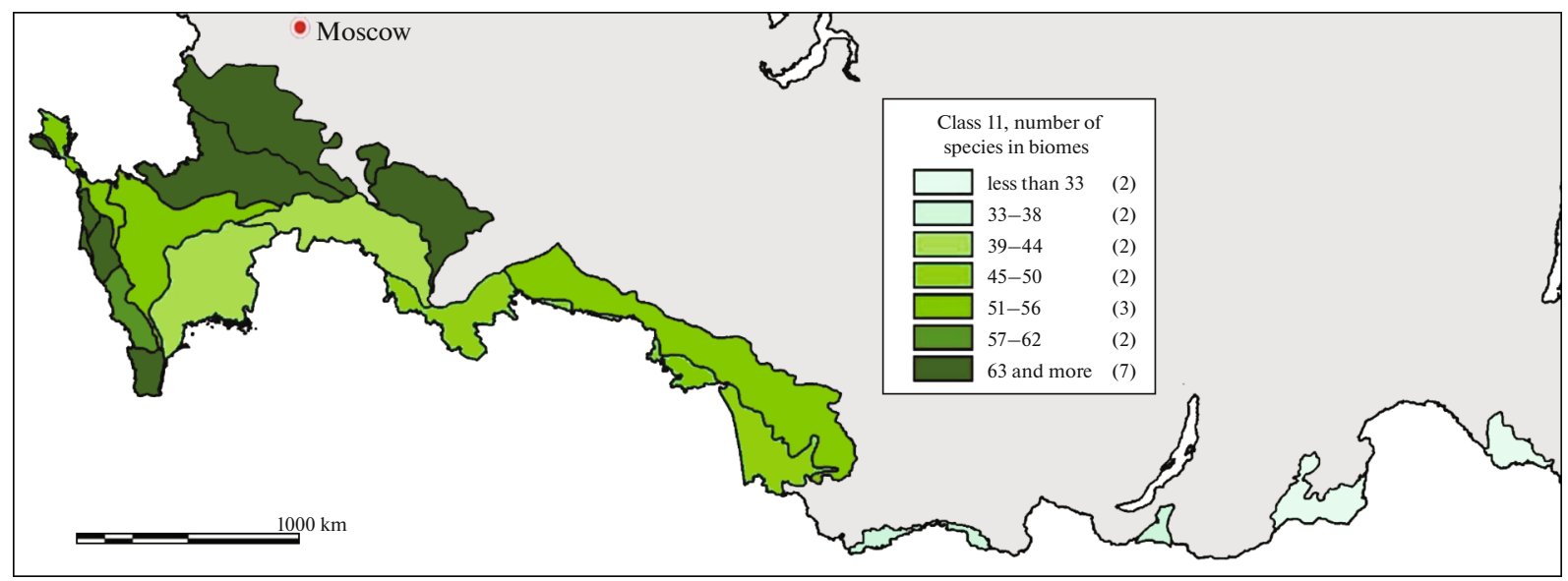

Fig. 8. Number of medicinal-plant species used to treat diseases of the digestive system (class 11) in biomes.

and a lower relationship with the amount of precipitation (0.50).

Plants used to treat class-10 diseases (respiratory diseases) have a high degree of association with the average temperature (0.63), a weaker association with the amount of precipitation (0.55), and the weakest association with the total biome species number (0.51).

Plants used to treat class-11 diseases (digestive organs) have a fairly high correlation with the total biome species number (0.68). Thus, the number of medicinal plants of individual classes is also related to the total number of medicinal species in biomes.

The closest relationship is established between the number of plant species used to treat diseases of the digestive system and the average annual temperatures (0.73). A relatively high relationship was found between the species number and the average annual precipitation (0.54).

However, the relationship between the number of plant species of all three considered classes with the AI is low and negative, as established above for the entire set of medicinal-plant species. Thus, the absence of clear links between the diversity of medicinal plants and the degree of territory aridity is confirmed.

The results are generally similar to the results obtained for the entire set of medicinal-plant species.

\section{CONCLUSIONS}

Analysis of the distribution of medicinal plants in semiarid and arid biomes showed the following.

-In the studied biomes, 214 species of medicinal plants were identified. The largest number of species includes the families Compositae (24 species), Rosaceae (19), legumes (13), and umbellates (12), which is generally typical for phytocenoses in the open spaces of meadow steppes, steppes, and desert steppes.

-The largest number of medicinal-plant species was noted for the largest Dnieper-Volga biome in terms of area. The smallest number of all such plants are noted for the Caspian desert biome.

- Medicinal plants used to treat diseases of the five most common disease classes according to the WHO classification grow in the studied regions.

Table 7. Pearson correlation coefficients by disease class

\begin{tabular}{l|c|c|c|c}
\hline \multirow{2}{*}{ Indices } & \multicolumn{5}{c}{ Factors } \\
\cline { 2 - 5 } & AI & average temperature, ${ }^{\circ} \mathrm{C}$ & amount of precipitation, mm & all types in biomes \\
\hline Class-9 medicinal species & -0.33 & 0.96 & 0.50 & 0.58 \\
Class-10 medicinal species & -0.17 & 0.63 & 0.55 & 0.54 \\
Class-11 medicinal species & -0.31 & 0.73 & 0.68 \\
\hline \multicolumn{5}{c}{ All medicinal types } \\
Class-9 medicinal species & \multicolumn{5}{c}{0.89} & 0.96 \\
Class-10 medicinal species & \multicolumn{5}{c}{0.99} \\
Class-11 medicinal species & & \multicolumn{5}{c}{} \\
\hline
\end{tabular}


-The largest number of medicinal-plant species in arid and semiarid biomes is used to treat diseases of the digestive system, circulatory system, and respiratory system.

-The greatest variety of medicinal plants used to treat diseases of the circulatory system is observed in the Black Sea-Ciscaucasia, Crimea-Novorossiysk, and the Kuban biomes.

-The greatest variety of medicinal plants used to treat respiratory diseases and diseases of the digestive system was noted for the Dnieper-Volga, Black SeaCiscaucasia, and Trans-Volga biomes, the mountain biomes of the Caucasus, and the Kuban steppe biome.

-The total number of medicinal-plant species is rather closely related to the total number of vascular plant species in biomes. This, in turn, is determined by the geographic location, which determines the average annual temperature and rainfall in biomes.

-The closest relationship is established between the total number of medicinal-plant species and average annual air temperatures. A relatively high relationship has been established between the species number and the average annual precipitation.

-The degree of association of medicinal diseases of the three classes selected for analysis with climatic indices is generally similar to the results obtained for the entire group of medicinal plants.

-The relationship between the number of medicinal-plant species and the De Martonne AI is very low, both for the entire set of species and for all three classes selected for analysis. This allows us to conclude that the number of medicinal-plant species in a biome has little to do with its aridity.

A similar analysis for other regions of Russia is planned for the future. The immediate task is to analyze the distribution of medicinal plants in Russia in connection with changes in climatic factors.

\section{ACKNOWLEDGMENTS}

The authors are grateful to N.B. Leonova for the provided database materials, "Medicinal plants of Russia." The authors are grateful to G.V. Surkova, who provided valuable advice on the analysis of climatic indices.

\section{FUNDING}

The work was carried out on the subject of State Assignment no. AAAA-A16-116032810082-6, "Diversity, dynamics, and monitoring of ecosystems in conditions of environmental changes."

\section{COMPLIANCE WITH ETHICAL STANDARDS}

Conflict of interests. The authors declare that they have no conflicts of interest.
Statement on the welfare of humans or animals. This article does not contain any studies involving animals performed by any of the authors.

\section{REFERENCES}

Agroekologicheskii atlas Rossii i sopredel'nykh stran: ekonomicheski znachimye rasteniya, ikh vrediteli, bolezni $i$ sornye rasteniya (Agroecological Atlas of Russia and Adjacent Countries: Economically Important Plants, Their Parasites, Diseases, and Weeds), Afonin, A.N., Grin, S.L., Dzyubenko, N.I., and Frolov, A.N., 2008. http://www.agroatlas.ru/. Accessed May 5, 2020.

Atlas arealov i resursov lekarstvennykh rastenii SSSR (Atlas of Ranges and Resources of Medical Plants of Soviet Union), Moscow: Glav. Uprav. Geodez. Kratogr., 1983.

Baltas, E., Spatial distribution of climatic indices in northern Greece, Meteorol. Appl., 2007, vol. 14, pp. 69-78.

De Martonne, E., Le Traité de Géographie Physique, Paris: Armand Colin, 1925.

Dikareva, T.V. and Rumyantsev, V.Yu., Cartographic analysis of the distribution of allergenic plants in Russia, Vestn. Mosk. Univ., Ser. 5: Geogr., 2015a, no. 6, pp. 34-40.

Dikareva, T.V. and Rumyantsev, V.Yu., Distribution of allergenic plants in Russia, Geogr., Environ., Sustainability, 2015b, vol. 8, no. 4, pp. 18-25.

Dikareva, T.V., Malkhazova, S.M., Rumyantsev, V.Yu., and Soldatov, M.S., Ecological and geographical analysis of the distribution of poisonous plants in Russia, Vestn. Mosk. Univ., Ser. 5: Geogr., 2017, no. 4, pp. 29-37.

Dikareva, T.V., Malkhazova, S.M., Rumyantsev, V.Yu., and Soldatov, M.S., Effect of arid conditions on the distribution of poisonous plants in the regional biomes of Russia, Arid Ecosyst., 2018, vol. 8, no. 1, pp. 64-72.

Grossgeim, A.A., Opredelitel' rastenii Kavkaza (Guide for Identification of the Caucasian Plants), Moscow: Sovetskaya Nauka, 1949.

Gubanov, I.A., Kiseleva, K.V., Novikov, V.S., and Tikhomirov, V.N., Opredelitel' sosudistykh rastenii tsentra Evropeiskoi Rossii (Guide for Identification of Vascular Plants of the Center of European Russia), Moscow: Argus, 1995.

Handbook on drought indicators and indices, 2016. https://www.droughtmanagement.info/literature/WMOGWP-Drought-Indices_ru_2016.pdf. Accessed May 14, 2020.

International statistical classification of diseases and related health problems, 10th revision (ICD-10), 2019. https://icd.who.int/. Accessed May 27, 2020.

Kazeev, K.S., Kozun', Yu.S., and Kolesnikov, S.I., Applying an integral index to evaluate the spatial differentiation of biological properties of soils along an aridity gradient in the south of Russia, Contemp. Probl. Ecol., 2015, vol. 8, no. 1, pp. 91-98.

Kotova, T.V. and Ogureeva, G.N., Biogeographic approaches to geobotanical cartography, in Geobotanicheskoe kartografirovanie (Geobotanical Cartography), St. Petersburg: Bot. Inst. im. V.L. Komarova, 2007, pp. 23-29. 
Lekarstvennye rasteniya Rossii (Medical Plants of Russia), Malkhazova, S.M., Mliklyaeva, I.M., Leonova, N.B., and Krainov, V.N., 2019. https://www.biomap.ru. Accessed May 3, 2020.

Mediko-geograficheskii atlas Rossii "Tselebnye istochniki $i$ rasteniya" (Medical-Geographic Atlas of Russia "Healing Springs and Plants"), Moscow: Mosk. Gos. Univ., 2019.

Nikolaevskii, V.V., Eremenko, A.E., and Ivanov, I.K., Biologicheskaya aktivnost' efirnykh masel (Biological Activity of Essential Oils), Moscow: Meditsina, 1987.

Ogureeva, G.N., Ecological-geographic approach to the analysis of diversity and geography of terrestrial ecosystems, in Voprosy geografii. Vyp. 134. Aktual'naya biogeografiya (Problems of Geography, No. 134: Relevant Biogeography), Moscow: Kodeks, 2012, pp. 55-77.

Ogureeva, G.N., Biodiversity of orobiomes of the North Caucasus on the map "Biomes of Russia," Yug Ross.: Ekol., Razvit., 2016, vol. 11, no. 1, pp. 21-36.
Ogureeva, G.N., Leonova, N.B., Emel'yanova, L.G., Buldakova, E.V., Kadetov, N.G., Arkhipova, M.V., Miklyaeva, I.M., Bocharnikov, M.V., Dudkov, S.V., Ignatova, E.A., Ignatov, M.S., Muchnik, E.E., Urbanavichyus, G.P., Danilenko, A.K., Rumyantsev, V.Yu., Leont'eva, O.A., et al., Karta “Biomy Rossii,” Masshtab 1: 7500000(A Map "Biomes of Russia,” Scale 1:7500000), Moscow: WWF Russia, 2018, 2nd ed.

Rubtsov, N.I., Opredilitel' vysshikh rastenii Kryma (Guide for Identification of Higher Plants of Crimea), Moscow: Nauka, 1972.

Sosudistye rasteniya sovetskogo Dal'nego Vostoka (Vascular Plants of Soviet Far East), in 7 vols., St. Petersburg: Nauka, 1995.

Zony $i$ tipy poyasnosti rastitel'nosti Rossii $i$ sopredel'nykh stran, Karta msshtaba 1:8000000 (Zones and Types of Zonality of Vegetation of Russia and Adjacent Countries: A Map, Scale 1 : 8000000 ), Ogureeva, G.N., Ed., Moscow: EKOR, 1999. 